\title{
An Error of Judgement. a play about the sexual abuse of people with learning disability
}

\author{
John H. M. Crichton
}

In recent years, psychiatrists have become much more aware of the sexual abuse of adults with a learning disability. Having struggled with such a case, which raised challenging problems of law, ethics and management (Crichton, 1997), I turned to the literature to help inform me about the subject. There I found helpful statistics from recent surveys, but sometimes such material fails to convey the true nature of what is a distressing and painful subject. To my astonishment I discovered that at a local theatre there was to be a performance on this very theme: $A n$ Error of Judgement. I had heard of the Strathcona Theatre Company ${ }^{1}$, a touring company of eight learning disabled professional actors who, with the assistance of two directors, devise the original plays they perform, but I had no idea of what the evening was going to be like.

From the literature about the sexual abuse of those with learning disability, Brown et al (1995) drew the following consensus of opinion: both men and women are victims; the perpetrators are most commonly men, known to the victim rather than strangers; perpetrators are commonly in positions of trust and authority; current perpetrators often will have abused victims in the past; and that there are four groups of perpetrator: staff, family, family friends, and others with a learning disability. Useful parallels may be drawn between the sexual abuse of adults with a learning disability and the abuse of children. Brown et al (1995) also comments that there continues to be much professional denial about the subject.

There are also great methodological problems in researching the subject; there are no accepted definitions of what constitutes abuse, sample sizes are small, and different researchers have used different screening methods. This has led to widely different estimates as to the size of the

1. The Strathcona Theatre Company can be contacted on 01714039316 for information about current and forthcoming performances. problem. Brown et al (1995) conducted a retrospective study into cases of sexual abuse of adults with a learning disability in a large regional health authority. Over a two-year period 31 cases were proven to the researcher's satisfaction and 54 highly suspected. The victims were both men and women, with an average age of 29 years and $61 \%$ had an estimated IQ of less than 50. In just over half the cases the victim was first to raise the issue of abuse, in $12 \%$ of cases overall the perpetrator confessed.

In Brown et al's (1995) study, of the 85 highly suspected or 'proven' cases, $91 \%$ of perpetrators were male, $81 \%$ were known to the victim, $53 \%$ were other service users, $20 \%$ were staff and $8 \%$ family members. In four cases the researchers could not find details of what happened following disclosure, of the remaining cases the police were involved in $42 \%$, and $6 \%$ resulted in prosecution. Several of the staff members accused of abuse resigned or moved following disciplinary procedures; $13 \%$ of learning-disabled perpetrators were moved.

The low prosecution rate in Brown et al's (1995) study may partly reflect the reluctance to bring prosecutions against perpetrators with a learning disability $(4 \%$ of user perpetrators were prosecuted compared to $14 \%$ of family member perpetrators), although the low numbers make any interpretation difficult. Low prosecution rates may also reflect the reluctance of courts to accept as reliable the evidence of learning-disabled witnesses. Unless there is support from physical forensic evidence, a confession, the testimony of a reliable witness or, in the cases where the defence is that of consensual sexual activity, evidence that the victim lacked the ability to consent, a prosecution is unlikely. Sanders et al (1997) concludes that the current legal system fails to protect vulnerable adults in this regard and other systems of surveillance and management are required. VOICE-UK is an organisation which campaigns for people with a learning disability who have been sexually abused. It was originally founded by Julie Boniface after the conviction of a care worker for the sexual abuse of her daughter. 
It is one thing to review the professional literature about such sexual abuse, it is quite another for the subject to be aired in theatre by people with a learning disability. While waiting for the performance to begin, I had the feeling of a 'busman's evening out' as I thumbed Makaton greetings to several familiar patients. About half the audience were made up of people with a learning disability, mostly in parties organised by their group homes; disappointingly the auditorium was not full. A sour faced man, who could have passed as Victor Meldrew, looked increasingly aghast as the complement of the audience became apparent; I concluded he would not stay the night.

Against a background of broken Grecian columns and with evocative music, the story unfolds of a corrupt ambitious politician, Maurice Hastings, and the principal of a college for the performance arts, Sir Charles Buckingham. Hastings kills his secretary and tries to hush it up, then sexually exploits Sarah, a learningdisabled arts student. The abuse is portrayed as a series of snapshot poses, which the audience sees in silhouette between scenes. The hero is Hastings' nephew Michael, also a learningdisabled arts student, who discovers Sir Charles' sexual interference with the male students. When Michael tries to tell his mother and uncle about Sir Charles he is told off for telling stories. As Michael learns about the abuse of Sarah, he also discovers that Hastings and Sir Charles are in cahoots and have been embezzling college funds.

A major theme was how the supportive relationships between the learning-disabled characters eventually led them to a just solution. The calm resolution of Sarah and Michael contrasted to the despotism and greed of Hastings and Sir Charles. Particularly effective were dance scenes between Sarah and Michael, beautifully choreographed, moving and meaningful. A great strength of the Strathcona production style is that it meets the audience at a range of intellectual levels. All the audience were transfixed by such scenes. In a 'play within a play' at the beginning, another dance scene portrayed the Three fates of greek mythology, who assign a person to good or evil and decide the length of life. They are: Clotho, the spinner of the thread of life; Lachesis, the measurer, who chooses one's lot in life; and Atropos, who cuts the thread of life at death. I did not expect this subtle reference to fate and destiny in a play about those society would consider to have been dealt a poor hand. Yet, the only disadvantage evident in the play results from the prejudice of, and exploitation by, the non-learning disabled. Indeed the professionalism of the whole production is testimony to the contribution that the learning disabled can make and their value in society.

If the politician was a little stereotypical in his corruption perhaps that was forgivable in the current context of political sleaze; the performance I saw was in the same week as the publication of the Nolan Report. There is some danger, however, in the good and bad characters being so distinct. One large group of people who sexually abuse the learning disabled are others with a learning disability, and I wondered how the company would have dealt with that theme. In the promotional material for the play, much is made about how the courts have difficulty in accepting the reliability of testimony from those with a learning disability. Cleverly, Michael discovers that Hastings and Sir Charles accidentally incriminated themselves on tape. It is doubtful that they would have met their just deserts if the only evidence against them were Michael's and Sarah's testimony.

When I sat down to watch An Error of Judgement I expected the positive message about the worth and rights of the learning disabled and the encouragement of the learning disabled to speak out when something is wrong. I had not really expected to have been so entertained and to have enjoyed the evening so much. $\mathrm{Mr}$ Meldrew still looked anxious at the interval but had mellowed by the end and applauded warmly; more than an adequate receptacle for my projections. I wonder if he was the local reviewer who wrote:

'It was a privilege to spend Thursday evening with the lively Strathcona theatre company. . . Their problem is that people think they have problems which they don't really have. They certainly had no problem in delivering a delightful and provocative production' (Moyle, 1997).

\section{References}

BROWN. H., STEIN, J. \& TURK, V. (1995) The sexual abuse of victims with a learning disability. Mental Handicap Research. 8. 3-24.

CRICHTON, J. H. M. (1998) Balancing restriction and freedom in the care of people with a learning disability: a case study. Journal of Intellectual Disability Research, in press.

MoyLE, N. (1997) An Error of Judgement, Theatre Royal, July 3. Bury Free Press, 11 July, p. 18.

SANDERS. A.. CREATON. J., BIRD. S.. et al (1997) Victims with Learning Disability. Negotiating the Criminal Justice System. Oxford: Oxford Centre for Criminological Research.

John H. M. Crichton, Lecturer in Psychiatry, Edinburgh University Department of Psychiatry, Kennedy Tower, Royal Edinburgh Hospital, Edinburgh EH1O $5 \mathrm{HF}$ 